\title{
THE EFFECT OF USING INQUIRY BASED LEARNING STRATEGY ON STUDENTS SPEAKING ABILITY ( A Case Study at SMAN 7 Bengkulu Selatan)
}

\author{
1) Yogi Irawan \\ ${ }^{2)}$ Syahrial \\ ${ }^{3)}$ Dedi Sofyan \\ yogiirawan300@gmail.com \\ Postgraduate Program of English Education \\ Department of Language and Art \\ Faculty of Teachers Training and Education \\ University of Bengkulu
}

\begin{abstract}
This research is aimed at finding out to what extent IBL strategy can affect students speaking ability and to find out the significant of IBL strategy on students speaking ability. The populations of this study were all students in second grade at SMAN 7 Bengkulu. The samples of this study were 30 students on one class of second grade at SMAN 7 Bengkulu Selatan. This study used quasi-experimental study with one group design in order to test hypotheses. The study was conducted by pretest, the treatment in three meetings by using IBL strategy and posttest to the students. The instruments of this study were pretest and posttest. The result of this research showed that there were increasing scores of students speaking ability from 40,27 to 51,33 , the increasing scores covered in; vocabulary aspect $(13,54)$, grammar aspect $(10,67)$, fluency aspect $(7,33)$, and pronunciation aspect $(12,67)$. The conclusions of the study were: firstly, IBL strategy affected students speaking ability with average increasing score of 11,05 covering the four aspects (vocabulary, gramar, fluency and pronunciation) of speaking. Secondly, IBL strategy affected sufficiently significant $(0,05)$ on students speaking ability. This current study contributes to give the teachers an additional strategy on the effective strategy for teaching of speaking.
\end{abstract}

\section{INTRODUCTION}

The teachers have to use the strategy in order to achieve the goal of the teaching process. The strategy in teaching is all the activites and steps in conducting instructions to support the process of learning in order to achieve the goal. According to Herrel and Jordan (2004), the strategy is defined as an approach which can be used accross particular areas to support the process of learning. Kindsvatter (1998), teachers' teaching strategy is a general approach of teachers in giving the students certain instructions in term of learning activities. Ritchhart, Church and Morrison (2011) declares that strategy is an approach to support learning of students that may be used only on one accassion. It means that the teaching strategy is an approach which is conducted by the teacher in one ocassion in order to support the learning activities.

The teachers' strategy is one of important aspects in teaching English to be considered. The teacher is a model of teaching and learning process that will make the teacher leads the process of pedagogical itself. The teachers should provide the strategy in teaching and learning process. Arends (2004), reveals that teacher 
should be able to use strategies for developing critical thinking and problem solving. Kindsvatter (1998), the teaching strategy is very influential aspect in students' learning experiencies and it is a critical component in deciding the extent of students' learning since teacher provides the vital human connection between the content and the environment of the students. It means that the teachers' strategy is needed in processing of teaching and learning process.

There are many kind of strategies which are used by the teachers in teaching of English such as: Cooperative Learning: The Jigsaw, Inquiry Based Instruction (Inquiry Based Learning), Differentiated Instruction: Learning Station, Graphic Organizers, and Utilizing Technology in the Classroom. It means that the teachers have to choose one of appropriate strategies in order to support the process of learning of their students. According to Ritchhart, Church and Morrison (2011) states the objective of strategy is to support the process of learning of the students.

In teaching of speaking, some strategies can be applied for developing speaking. there are three teaching strategies which can be used by the teachers in teaching of speaking based on NCLRC (National Capital Language Resources Center.2004). The first strategy is using minimal responses. Minimal responses are predictable, often idiomatic phrases that conversation participants use to indicate understanding, agreement, doubt, and other responses to what another speaker is saying. The second strategy is recognizing scripts. The teacher can help students to develop speaking ability by making them aware of the scripts for different situations so that they can predict what they will need to say in response. The third strategy is using language to talk about language. The teacher can help students overcome the problem of students when they are speaking by clarification and comprehension check.

IBL is one of the effective strategies that can be applied in the classroom activities. It makes students to be involved in teaching and learning process. IBL is more than a strategy for learning but it is an attitude towards life that implies students' involvement in facing and solving a problem the search for realistic and strategic solutions (ITEC.intel teach essentials courses: 2013). There are five stages in the process of IBL. They are asking stage, investigating stage, creating stage, discussing stage and reflecting stage (Escalante.2013).

Inquiry based learning is one of strategies that can be used by the teachers in teaching of speaking. Inquiry-based learning is an approach to teaching and learning that places students' questions, ideas, and observations at the center of the learning experience (CBS:2013). According to Scardamalia (2002), in IBL (Inquiry-based learning), the teachers play an active role throughout the process by establishing a culture where ideas are respectfully challenged, tested, redefined and viewed as improvable, moving children from position of wondering to a position of enacted understanding and further questioning. Kuklthau, Maniotes \& Caspari (2007), states that inquiry requires more than simply answering questions or getting a right answer. It espouses investigation, exploration, search, quest, research, pursuit, and study. It is enhanced by involvement with a community of learners, each learning from the other in social interaction.

Inquiry-Based learning strategy is one of the effective strategies in teaching of speaking. It makes students be motivated to engage to the classroom activities. According to CBS (Capacity Building Series.2013), inquiry based 
learning offers promise in supporting students to become thoughtful, motivated, collaborative, and innovative learners capable of engaging in their own inquiries and thriving in a world of constant change. It means that by inquiry learning strategy, students can determined their topic that they interested in and students can engage to the process of activities in speaking.

There are many investigations about the use of Inquiry-Based Learning (IBL) strategy for some skills in teaching of English such as: IBL for developing listening skill, IBL for developing reading comprehension and IBL for improving writing ability. Anyhow the IBL strategy is effective for teaching of English which is supported by literature, but the IBL strategy has a chance to be applied on developing speaking ability. This is the main factor in this current study; in particular, it is aimed at investigating about the effect of using IBL strategy in students speaking ability.

\section{METHODS}

This research was classified as quasi-experimental study with one group design, pre and posttest in order to test hypotheses. According to Horvart (2016), "quasi-experimental design can be operationally for theory building as: (i) nonrandomized control group pretest and posttest study, (ii) time series based study, (iii) control group time series study, (iv) equivalent time sample series study. In time series based study, it derives a theory about the phenomenon considering one group only". Sherbiny (2007), "quasi-experimental study is an approach which seeks to uncover the relationships between variables in a rate controlled conditions in which a researcher on a variable rate can see the conditions that cause specific phenomenon, therefore, variable is a deliberate change to set the conditions for what happened and note the changes in the event itself". The study used all students at SMAN 7 Bengkulu as the population.

The sample was one class consists of 30 students in the middle level of second grade at SMAN 7 Bengkulu Selatan. The study used purposive sampling as a technique to take a sample. Singh (2006) states that purposive sampling is selected by some arbitrary methods because it is known to be representative of the total population, or it is known that it will produce well matched groups. The study will use two variables as following: The independent variable: Using Inquiry-Based Learning Strategy and the dependent variable: Speaking ability. The study used Cronbach's Alpha to measure the reliability of the test. In this study, the researcher conducted following some activities as: The researcher prepared pre-test and post-test on November $5^{\text {th }}$ 2017. The researcher gave the pretest to the students on November $6^{\text {th }} 2017$. The researcher did the treatment by using IBL strategy to the students on November $7^{\text {th }} 2017$ until November $30^{\text {th }}$ 2017. The researcher did the posttest after the treatment on December $2^{\text {nd }} 2017$. The researcher analyzed the data based on the result of pretest and posttest on December $4^{\text {th }}$ 2017. The researcher concluded the result based on analysis of pretest and post on December $11{ }^{\text {th }} 2017$. The researcher collected the data from all samples taken. The researcher collected the data from pretest and posttest. All the data from pre-test and post-test were analyzed based on the theory. The data 
was measured by using assessment criteria for speaking aspects with ordinal scale of Likert scale. They were numerical number like the following below:

\begin{tabular}{|c|c|c|c|c|c|}
\hline \multirow{3}{*}{ Scale } & $\begin{array}{c}\text { Very } \\
\text { poor }\end{array}$ & Poor & Good & Very good & Excellent \\
\cline { 2 - 6 } & 1 & 2 & 3 & 4 & 5 \\
\hline
\end{tabular}

The researcher concluded the preliminary results of data statistically as following:

1. The scoring data based on the criteria for speaking aspects which was adapted from Harries (1984) and Hughes (2003).

2. The data was analyzed by table of analysis on students speaking ability and it was converted to students' mark and score each aspects as following below:

$$
\begin{aligned}
\text { Students' mark } & =\frac{\text { Students' score }}{\text { Max. Score }} 100 \\
\text { Score each aspects } & =\frac{\text { Score per criteria }}{\text { Max score }} \times 100
\end{aligned}
$$

3. The data was concluded by analysis in Wilcoxon test in order to know the significant of pre \& posttest on students speaking ability.

\section{RESULTS AND DISCUSSION RESULT}

There are two research questions in this study that were answered descriptively by the data in this chapter. The first is to what extent IBL strategy can affect students speaking ability. The second is how the significant of IBL strategy on students speaking ability.

This study was held from November $06^{\text {th }}$ until December $11^{\text {th }} 2017$. The researcher gave the pretest to the students on November $6^{\text {th }} 2017$. The researcher conducted the treatment in three meetings by using IBL strategy to the students on November $7^{\text {th }} 2017$ until November $30^{\text {th }}$ 2017. The researcher did the posttest after three meeting treatments on December $2^{\text {nd }} 2017$.

The treatments were conducted based on the result of pretest. The researcher applied IBL strategy in speaking teaching process. The researcher applied five stages or cycles of IBL strategy in every meetings. The first stage or cycle was asking stage, the researcher wrote down the topic of the lesson and students made own questions related to the topic. The second stage was investigating stage, the researcher directed the students to search the information about the topic and students searched the information based on the topic. The third stage or cycle of IBL strategy was creating stage, the researcher directed the students to make a list of questions based on their sources that they have found it and students make a list of questions related to the topic. The fourth stage of IBL strategy was discussing stage, the researcher directed students to discuss in groups 
related to the topic and students discussed in each group. The fifth stage of IBL strategy was reflecting stage, the researcher directed students to make conclusion about the topic that they have discused and students made conclusion about the topic.

The result showed that students felt interested in learning of speaking after three meeting treatments conducted by applying IBL strategy. It showed almost of students spoke in English even though a few of them just talked a litle conversation. The students got improvement in their motivation and involvement to the process of teaching speaking. This chapter described and showed in details about students speaking ability based on the result of pretest and posttest.

\section{The Result of Pre- test}

The researcher conducted pre-test on Sunday, November $6^{\text {th }}$ 2017. The result of pretest was analyzed based on speaking test criteria which was adapted from Harries (1984) and Hughes (2003). The data was shown in the graphic below: 


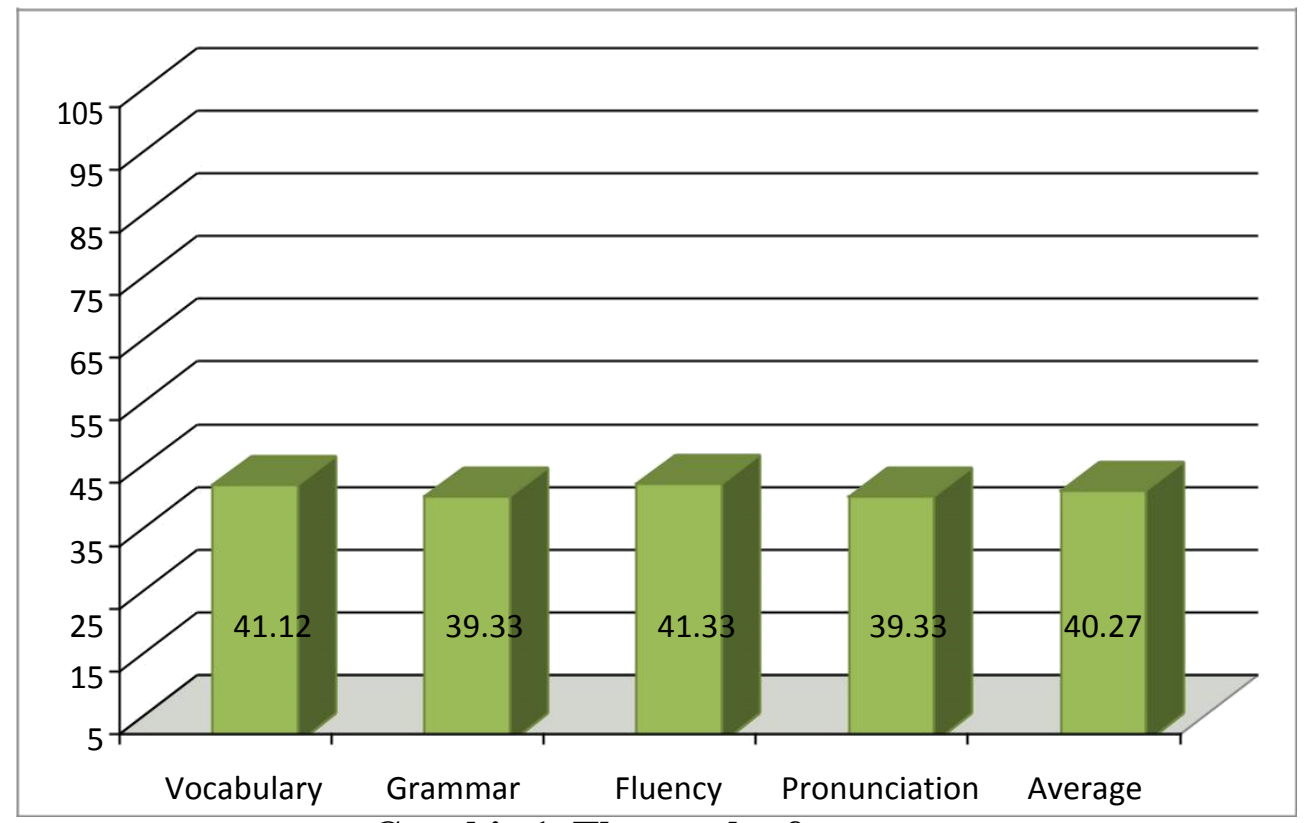

Graphic 1. The result of pretest

Based on the graphic above, it shows that the result of pretest in vocabulary aspect is 41,12 . It means that the speaking ability of students in the aspect of vocabulary before the treatments is 41,12. In grammar aspect, the result of pretest 39,33. It means that the students speaking ability scores in grammar aspect before the treatments are 39,33. In fluency aspect, the result shows that there are 41,33 of students speaking ability in pretest. It means that students ability scores in fluency aspect are 41,33 before the treatments conducted. In pronunciation aspect, the result of pretest shows that there are 39,33 of students speaking ability. It means that students speaking ability scores in pronunciation aspects before the treatments are 39,33. In the average score, there are 40,27 of students scores as the result of pretest which is covering the four aspects of speaking.

\section{The Result of Post- test}

In conducting the research, the researcher did posttest after three meeting treatments by applying IBL strategy. The researcher conducted posttest on Saturday, December $2^{\text {nd }} 2017$. The researcher gave students description about what students had to do. The researcher asked students to speak in front of the class with duration 1 until 2 minutes to perform English by the topic that the were interested. Before the test began, the researcher gave them to prepare their materials to be presented in 15 minutes. The result of posttest was shown detail in the graphic below: 


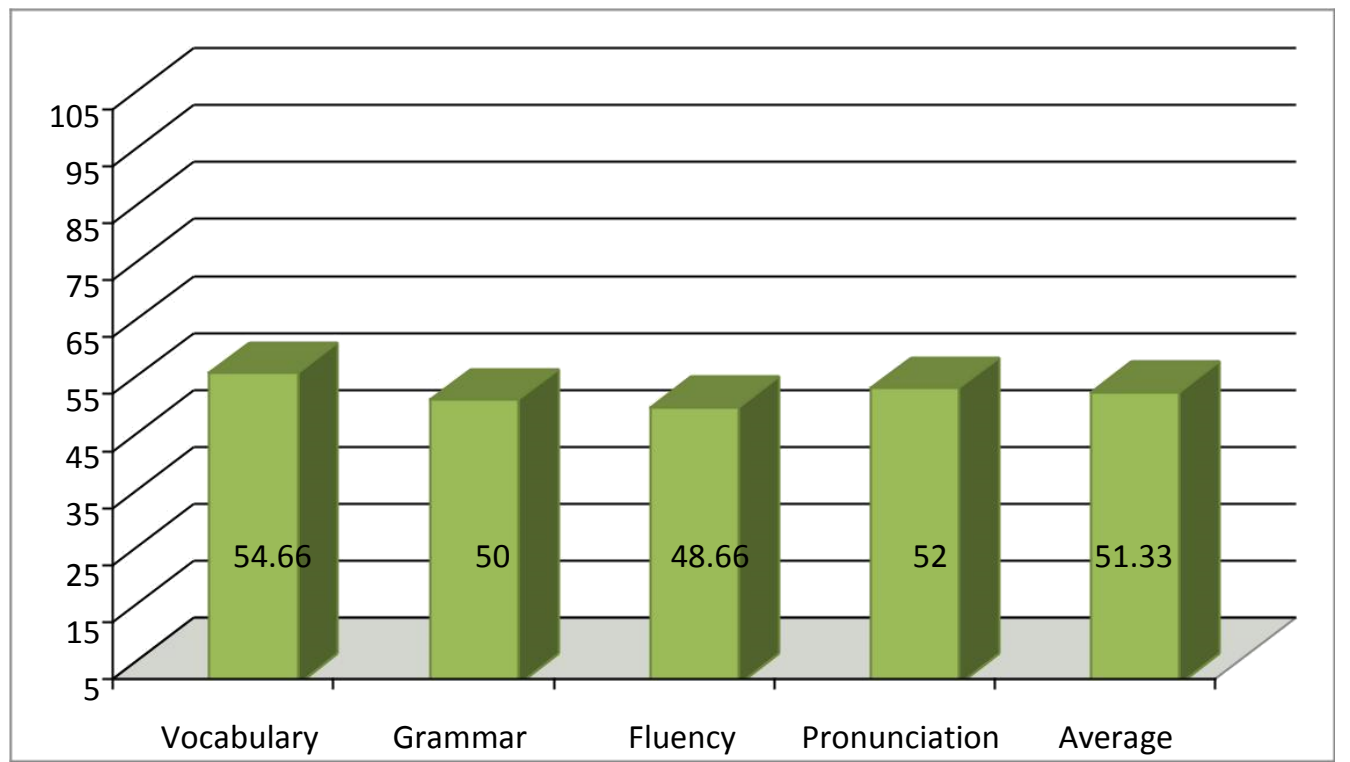

Graphic 2. The result of post-test

Based on the graphic above, the result shows that in vocabulary aspect, there are 54,66 of posttest result. It means that students speaking ability scores in vocabulary aspect after three meeting treatments conducted are 54,66. In grammar aspect, the result of posttest shows that there are 50. It means that students speaking ability scores in grammar aspect after the three meeting treatments done are 50. In fluency aspect, the result shows that there are 48,66. It means that students speaking ability scores in fluency aspect after the three meeting treatments conducted are 48,66. In pronunciation aspect, the result shows that there are 52 of pronunciation score. It means that students speaking ability scores in fluency aspect after three meeting treatments are 52. In average score, there are 51,33 of students scores which is covering four aspects in speaking as a result of posttest.

\section{The Result of Speaking Test in Vocabulary Aspect}

In order to see the effect of IBL strategy on students speaking ability, the researcher describes the differences of the result between pretest and posttest, the researcher describes in details students speaking ability result test in vocabulary aspect on the table below:

Table 2. The Result of Speaking Test on Vocabulary Aspect

\begin{tabular}{|r|c|r|r|r|r|r|r|r|r|r|r|}
\hline No & Aspect & \multicolumn{4}{|c|}{ Pretest score } & \multicolumn{5}{c|}{ Posttest score } \\
\hline 1 & Vocabulary & $\mathbf{1}$ & $\mathbf{2}$ & $\mathbf{3}$ & $\mathbf{4}$ & $\mathbf{5}$ & $\mathbf{1}$ & $\mathbf{2}$ & $\mathbf{3}$ & $\mathbf{4}$ & $\mathbf{5}$ \\
\cline { 3 - 11 } & & $4 \mathrm{p}$ & $20 \mathrm{p}$ & $6 \mathrm{p}$ & - & - & & $8 \mathrm{p}$ & $22 \mathrm{p}$ & - & - \\
\hline 2 & Result score & \multicolumn{4}{|c|}{41,12} & \multicolumn{5}{c|}{54,66} \\
\hline
\end{tabular}




\begin{tabular}{|r|c|c|}
\hline 3 & $\begin{array}{c}\text { Increasing } \\
\text { score }\end{array}$ & 13,54 \\
& & \\
\hline
\end{tabular}

( $\mathrm{P}$ = participant, $1=$ =very poor, $2=$ =poor, $3=$ good, $4=$ =rery good, $5=$ =xcellent $)$

Based on the table above, in pretest score, there are 4 participants get score 1, 20 participants get score 2 and 6 participants get score 3 . In posttest score, there are 8 participants get score 2 and 22 participants get score 3 . The result scores of pretest are 41,12 and the result scores of posttest are 54,66. It shows that there are 13,54 of increasing score of students speaking ability from pretest to posttest. It seems that IBL strategy can affect students speaking ability in vocabulary aspect in increasing score 13,54.

\section{The Result of Speaking Test in Grammar Aspect}

The table below describes the differences of the result between pretest and posttest, the table describes in details about the effect of IBL strategy on students speaking ability based on the result test in grammar aspect.

Table 3. The Result of Speaking Test on Grammar Aspect

\begin{tabular}{|c|c|c|c|c|c|c|c|c|c|c|c|}
\hline No & Aspect & \multicolumn{5}{|c|}{ Pretest score } & \multicolumn{5}{|c|}{ Posttest score } \\
\hline \multirow[t]{2}{*}{1} & Grammar & 1 & 2 & 3 & 4 & 5 & 1 & 2 & 3 & 4 & 5 \\
\hline & & $7 \mathrm{p}$ & $17 \mathrm{p}$ & $6 p$ & - & - & & $15 \mathrm{p}$ & $15 \mathrm{p}$ & - & - \\
\hline 2 & Result score & \multicolumn{5}{|c|}{39,33} & \multicolumn{5}{|c|}{50} \\
\hline 3 & $\begin{array}{c}\text { Increasing } \\
\text { score }\end{array}$ & \multicolumn{10}{|c|}{10,67} \\
\hline
\end{tabular}

( $\mathrm{P}=$ participant, $1=$ very poor, $2=$ poor, $3=$ good, $4=$ =ery good, $5=$ excellent $)$

Based on the table above,in pretest score, it shows that there are 7 participants get score 1, 17 participants get score 2 and 6 participants get score 3 . In post score, there are 15 participants get score 2 and 15 participants get score 3. The result scores of pretest are 39,33 and the result scores of posttest are 50. It shows that there are 10,67 of increasing scores of students speaking ability between pretest and posttest. It seems that IBL strategy can affect students speaking ability in grammar aspect of increasing score 10,67 of it's effect.

\section{The Result of Speaking Test in Fluency Aspect}

The table below shows the differences between pretest and posttest result. The table describes in details about the effect of IBL strategy on students speaking ability based on the result test in fluency aspect. 
Table 4. The Result of Speaking Test on Fluency Aspect

\begin{tabular}{|c|c|r|r|r|r|r|r|r|r|r|r|}
\hline No & Aspect & \multicolumn{5}{|c|}{ Pretest score } & \multicolumn{5}{c|}{ Posttest score } \\
\hline 1 & Fluency & $\mathbf{1}$ & $\mathbf{2}$ & $\mathbf{3}$ & $\mathbf{4}$ & $\mathbf{5}$ & $\mathbf{1}$ & $\mathbf{2}$ & $\mathbf{3}$ & $\mathbf{4}$ & $\mathbf{5}$ \\
& & & & & & & & & & & \\
\cline { 2 - 10 } & $4 \mathrm{p}$ & $20 \mathrm{p}$ & $6 \mathrm{p}$ & - & - & $2 \mathrm{p}$ & $13 \mathrm{p}$ & $15 \mathrm{p}$ & - & - \\
\hline 2 & Result score & \multicolumn{6}{|c|}{41,33} & \multicolumn{6}{c|}{48,66} \\
\hline 3 & $\begin{array}{c}\text { Increasing } \\
\text { score }\end{array}$ & \multicolumn{10}{|c|}{7,33} \\
\hline
\end{tabular}

Based on the table above, in pretest result score, there are 4 participants get score 1, 20 participants get score 2 and 6 participants get score 3 . In posttest score, there are 2 participants get score 1, 13 participants get score 2 and 15 participants get score 3. The result scores of pretest are 41,33 and the result scores of posttest are 48,66. It shows that there are 7,33 of increasing score of students speaking ability between pretest and posttest. It seems that IBL strategy can affect students speaking ability with increasing score 7,33 in fluency aspect.

\section{The Result of Speaking Test in Pronunciation Aspect}

In the table below, it shows the effect of IBL strategy on students speaking ability, the table shows the differences of the result between pretest and posttest, the table describes in details students speaking ability result test in pronunciation aspect.

Table 5. The Result of Speaking Test on Pronunciation Aspect

\begin{tabular}{|l|c|r|r|r|r|r|r|r|r|r|r|}
\hline No & Aspect & \multicolumn{4}{|c|}{ Pretest score } & \multicolumn{5}{c|}{ Posttest score } \\
\hline 1 & Pronunciation & $\mathbf{1}$ & $\mathbf{2}$ & $\mathbf{3}$ & $\mathbf{4}$ & $\mathbf{5}$ & $\mathbf{1}$ & $\mathbf{2}$ & $\mathbf{3}$ & $\mathbf{4}$ & $\mathbf{5}$ \\
& & $8 \mathrm{p}$ & $15 \mathrm{p}$ & $7 \mathrm{p}$ & - & - & $2 \mathrm{p}$ & $11 \mathrm{p}$ & $\begin{array}{c}14 \\
\mathrm{p}\end{array}$ & $3 \mathrm{p}$ & - \\
\hline 2 & Result score & \multicolumn{1}{|c|}{39,33} & & & & & \\
\hline 3 & $\begin{array}{c}\text { Increasing } \\
\text { score }\end{array}$ & \multicolumn{10}{|c|}{12,67} \\
\hline
\end{tabular}

Based on the table above, in pretest score, there are 8 participants get score 1, 15 participants get score 2 and 7 participants get score 3 . In posttest score, there are 2 participants get score 1, 11 participants get score 2, 14 participants get score 3, and 3 participants get score 4 . The result scores of pretest are 39,33 and the result scores of posttest are 52. It shows that there are 12,67 of increasing score of students speaking ability from pretest to posttest. It 
means that IBL strategy can affect students speaking ability in pronunciation aspect in score 12,67.

\section{The Result of Speaking Test on the Four Aspects}

The results of pre-test and post-test were drawn by the graphic below in order to know the increasing score of students speaking ability from pretest to post.

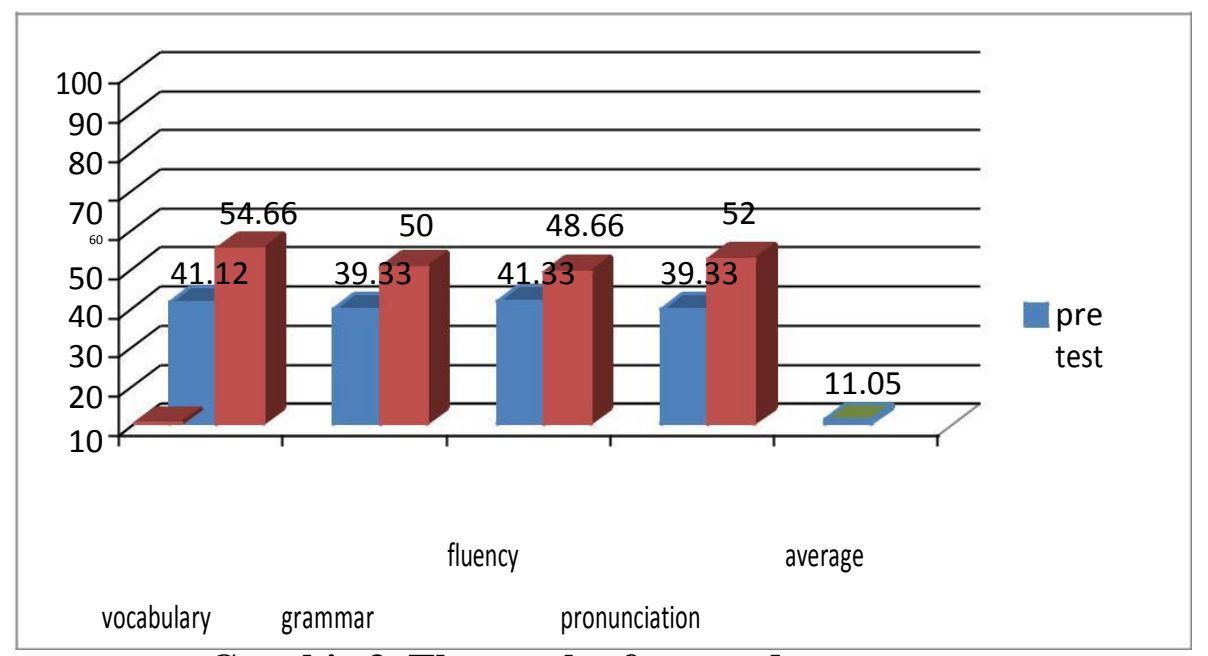

Graphic 3. The result of pre and posttest

Based on the graphic above, it can be seen that in vocabulary aspect, there are 41,12 of result score in pretest and there are 54,66 of result score in posttest. In grammar aspect, there are 39,33 of result score in pretest and there are 50 of result score of posttest. In fluency aspect, there are 41,33 of result score in pretest and there are 48,66 of result score of posttest. In pronunciation aspect, there are 39,33 of pretest score and there are 52 of result score in posttest. The averages of increasing score of students speaking ability in the four aspects (vocabulary, grammar, fluency and pronunciation) are 11,05. It means that IBL strategy can affect students speaking ability with about 11,05 of increasing score of students speaking ability from pretest to the posttest after the treatments by applying IBL strategy.

\section{The result of Speaking Test by Wilcoxon Analysis}

The result of this study was analyzed by Wilcoxon test in order to know the significant of IBL strategy towards students speaking ability. Wilcoxon is one of application of SPSS program which was used to find the significant result between pretest result and posttest result. the details result will be reportedly below. 
Table 6. Descriptive Statistics

\begin{tabular}{|l|l|l|l|l|}
\hline & $\mathrm{N}$ & Mean & Minimum & Maximum \\
\hline PRE & 30 & 40.33 & 20 & 60 \\
POST & 30 & 50.50 & 35 & 65 \\
\hline
\end{tabular}

Based on the table above, the result shows that the average scores (mean scores) of 30 students as participants of pretest are 40,33 and the average scores (mean score) of 30 students as participants in the posttest are 50,50. The result also shows that there are 20 as minimum score of students and there are 60 as maximum score of students in the pretest. In posttest, there are 35 as minimum score of students and 65 as maximum score of students.

Table 7. Wilcoxon Signed Ranks Test

\begin{tabular}{|ll|l|l|l|}
\hline & & $\begin{array}{l}\text { Mean } \\
\text { Rank }\end{array}$ & Sum of Ranks \\
\hline POST - & Negative Ranks & $0^{\mathrm{a}}$ & .00 & .00 \\
PRE & Positive Ranks & $28^{\mathrm{b}}$ & 14.50 & 406.00 \\
& Ties & $2^{\mathrm{c}}$ & & \\
& Total & 30 & & \\
& & &
\end{tabular}

Based on the table above, wilcoxon rank test shows that there is no negative rank of total participant so the test can be carried out to the next stage of analysis by Wilcoxon statistics below.

Table 8. Test Statistics

\begin{tabular}{|l|l|}
\hline & $\begin{array}{l}\text { POST - } \\
\text { PRE }\end{array}$ \\
\hline $\begin{array}{l}\text { Asymp. Sig. (2- } \\
\text { tailed) }\end{array}$ & .000 \\
\hline
\end{tabular}

Based on the result of test statistics in Wilcoxon analysis table above, the result of the table shows that there are 0,000 in sig. (2tailed) which meant that the result test is less than a minimum requirements of statistics range $0,05(0,05)$. It means that the first hypothesis $\left(\mathrm{H}_{0}\right)$ is denied and the second hypothesis $\left(\mathrm{H}_{1}\right)$ is accepted. It shows that that there are statistically significant differences at (0.05) in the mean scores in pre \& post speaking test. It means that IBL strategy is significant in improving students speaking ability. 


\section{Discussion}

\section{To what extent IBL strategy can affect students speaking ability}

Based on the result of the study, the result reveals that IBL strategy can give effect to students speaking ability with the average score result 11,05 of increasing students speaking ability from pretest to posttest. It was shown by previous studies that was conducted by Mendur, Mogea \& Olii (2014), entitled Increasing students' ability of writing descriptive texts based on Inquiry-based learning at SMA Kristen Tondano. The result of the study showed that Inquirybased learning is effective to teach the students how to think critically in order to improve students writing ability. Sulastri (2012) entitled "Improving the students' reading skill by Using Inquiry-Based Learning Method" (A clasroom Action Research at the eighth Grade of SMPN 2 Barat-Magetan in 2011/2012 Academic Year. The result of the study showed that IBL strategy can improve students' reading comprehension and students are able to comprehend a text better. It means that IBL strategy not only give effects to writing ability and reading ability of students but also IBL strategy can give effects on students speaking ability.

There are four aspects in speaking ability which are focused in this study. The first is vocabulary aspect, the second is grammar aspect, the third is fluency aspect and the fourth is pronunciation aspect. Those aspects were discussed by details based on the result of speaking pretest and posttest.

\section{Vocabulary Aspect in Speaking}

Based on the result of speaking pre and posttest data, IBL strategy gave effects to students speaking ability with increasing score of students speaking ability 13,54 in vocabulary aspect. It indicates that IBL strategy can give students a chance to improve their vocabularies. It shows that IBL strategy can make students to explore their knowledge. According to Abdelraheem and Asan (2006), Inquiry-Based Learning is the strategy to explore students' knowledge. It means that, by applying IBL strategy, students have chances to explore their abilities so that they can improve or gain their vocabularies.

Creating stage in IBL strategy can give students many chances to make an idea rellated to the information that they get from sources. According to Escalante (2013), the creating stage is where students practice their composition skill. It means that students can get many new words as a result by getting new information or making list of information related to the topic that they discussed. By getting new information, students have learned and gained their vocabularies indirectly.

\section{Grammar Aspect in Speaking}

Based on the result of speaking test in grammar aspect, there were 10,67 of increasing score of students speaking ability between pretest and posttest score. It means that IBL strategy can affect students speaking ability in grammar aspect by improvement scores in 10,67 of its effect.

By applying IBL strategy in classroom activities, students can produce sentences repeatedly until the correct one. It indicates that students can improve their grammar by producing sentences through making a list of questions. Students feel confident in making sentences or questions because they feel handle or control the class activities by themselves. According to Brown (2000), students who can use IBL strategy are better language learners. Students can be more 
active in the class. They can be motivated to pay attention in class and to be interested in involving the process of teaching and learning because they feel handle or control their language level.

Grammar is one of aspects in speaking must be improved by students in this case. It needs improvements because the students have to pay attention to their grammar in order to make appropriate mechanism when they speak to others or communicate to each other. Leech (2003), grammar is a reference to mechanism according to which language works when it is used to communicate with other people. It means that Grammar is a mechanism for putting words together. It means that grammar is one of aspects in speaking must be considered by students.

\section{Fluency Aspect in Speaking}

Fluency is the speed of producing the words by students in such sequencing time. According to Nunan (2003), "fluency is the ease and speed with which a student is able to formulate and generate speech in the target language. It comes mainly through contextual speaking practice, not drilling with isolated words".

Based on the result of pretest and posttest, there were 7,33 of increasing score of students speaking ability between pretest and posttest. It means that IBL strategy effects toward students speaking ability were 7,33 of increasing score in fluency aspect. It indicates as a result that the more active intensity of students in speaking can increase students' fluency however it is only 7,33 from the result score. Creedy (1992) states that IBL is intended to encourage the students to be active in the calssroom activities. It means that IBL strategy can affect students' fluency in their speaking by increasing their involvement in the process of teaching.

The more active students in classroom activities will make students to be fluent in speaking itself. Thornbury (2005) states that speaking is like any other skill, such as driving or playing a musical instrument: the more practice you get, the more likely it is you will be able to chunk small units into larger ones and achieve fluency". It means that the more active students in practicing of speaking so it will make increasing of their fluency.

There are two problems in students' fluency. One of them is some students still feel afraid when they speak in classroom activities. It causes they cannot improve their fluency as a result they do not involve to the speaking itself when IBL strategy was applied. This is the cause of increasing score of fluency aspect in speaking which is lower than other aspects.

Other problems which effect of students' fluency is lack of time in students explore their speaking. Students cannot speak more because the time in the process of teaching is lack. The sufficient time is needed in the process of Speaking. It causes speaking is practicing process. Although the teachers give many chances to speak in the classroom process through applying IBL strategy in the class however the time of English class particularly on high school is limited. It is suitable with one of the teaching speaking principles by Brown (2000) which is "reducing the teachers speaking time in class while increasing students speaking time". 


\section{Pronunciation Aspect in Speaking}

Based on the result of pretest and posttest in pronunciation aspect, it showed that there were 12,67 of increasing score of students speaking ability from pretest to posttest. It means that IBL strategy can affect students speaking ability in pronunciation aspect by increasing score 12,67.

By applying IBL strategy in the process of teaching speaking, the students can be active in the process of teaching. According to Escalante (2013), IBL strategy allows an active participation of students. It shows that IBL strategy can make students more active in the process of learning of speaking. Students can practice how to pronounce the words as a result they have chances to produce many words correctly.

The result indicates that by practicing the production of the words frequently, the result of speaking particularly on pronunciation will be improved. Scoot (2005) states that speaking is the productive and oral skill. Speaking is a cognitive skill, is the idea which knowledge become increases automatically through successive practice. It means that the result can be improved because the process of practicing the speaking is successful as a result it can make students' pronunciation especially is improved even though it is not too much in percentage result.

The pronunciation aspect is one of important aspects to be considered by the speakers particularly on students high schools. It can determine whether they are mastering such a language especially English or not. In addition, by pronunciation aspect, the hearer can determine that the speaker is native or nonnative. Brown (2000), states that pronunciation refers to how people pronounce the words. This is because people tend to judge native/non-native speaker status on the basis of pronunciation.

There are two general factors which can affect students' pronunciation. those are internal factor and external factor. Internal factor is coming from students itself such as: exposure, age and motivation. And external factors are coming from outside of students such as: teachers, strategy of learning and classroom setting. In this case, the researcher tries to discuss in internal factors. It is related to the study after applying IBL strategy in classroom activities toward students speaking ability particularly on pronunciation aspect. According to Kenworthy (1987), there are six factors within the learners that affect pronunciation. Those factors are native language, age, exposure, innate phonetic ability, identify and language ego, and motivation and concern for good pronunciation.

Based on the result of this study particularly on students' pronunciation, there are two factors appear as the implication factors which influence students pronunciation which are still under 15 of increasing score result from pretest to posttest. The first factor is exposure. The exposure factor means that the intensity of showing such speaking practices or conversation naturally in English are rare. Exposure is important to the students to improve their pronunciation. Kenworthy (1987), states that the quality and intensity of exposure are more important than mere length of time.

The second factor which can affect students' pronunciation is motivation and concern for good pronunciation. Although one of benefits of IBL strategy is to motivate students to involve to the process of learning, some students still having lack motivation towards learning process. According to Brown (2000), if the motivation and concern of good pronunciation are high, then the necessary 
effort will be expended in pursuit of goals. It means that if the students' motivation is improved so the students' pronunciation also in this case will be improved as well.

\section{How Significant IBL strategy on Students Speaking Ability}

There are two hypotheses in this study. The first hypothesis is "there are not statistically significant differences at (0.05) in the mean scores in pre \& post speaking test $\left(\mathrm{H}_{0}\right)$ ". The second hypothesis is "there are statistically significant differences at $(0.05)$ in the mean scores in pre \& post speaking test $\left(\mathrm{H}_{1}\right)$ ".

Based on the result of speaking pretest and posttest which was analyzed by Wilcoxon test, the result showed that the first hypothesis $\left(\mathrm{H}_{0}\right)$ was denied and the second hypothesis $\left(\mathrm{H}_{1}\right)$ was accepted. It means that there are statistically significant differences at (0.05) in the mean scores in pre \& post speaking test.

The result showed that IBL strategy gave the significant impact on students speaking ability. It is similar to some previous studies. Sholeh (2008) entitled "Using Inquiry-Based Learning Strategy to Improve Descriptive Writing Ability of the Second Year Students of MTs. Al Ikhwan Klitih Demak". The result of the study showed that IBL strategy can improve students' writing skill. Sulastri (2012) entitled " Improving the students' reading skill by Using Inquiry-Based Learning Method" (A classroom Action Research at the eighth Grade of SMPN 2 Barat-Magetan in 2011/2012 Academic Year. The result of the study showed that IBL strategy can improve students' reading comprehension and students are able to comprehend a text better. It means that IBL strategy can improve not only for writing and reading skill but also can improve for speaking skill.

Based on the result of this study, there are two factors which can determine the significant impact of IBL strategy on students speaking ability. They are the factor within IBL strategy itself and the factor outside of IBL strategy. The factor within IBL strategy is the factor that comes from the stages in IBL strategy itself and the factor outside of IBL strategy is supporting factors outside of those of five stages in IBL strategy such as: environment, teachers, and students.

\section{The Factor within IBL Strategy}

There are five stages or cycles of IBL strategy which are used in the classroom activities particularly on this case teaching of speaking. According to Escalante (2013), there are five stages in IBL strategy namely: asking stage, investigating stage, creating stage, discussing stage, and reflecting stage.

On the first stage, students have to plan their tasks and formulate meaningful questions about a problem or topic which they have to discuss as a part of unit of study. It gave students many chances to determine their interested topic so that they can easily follow the learning experiences. According to Escalante (2013), IBL strategy can encourage the development of critical thinking. By applying IBL strategy, students make questions based on their background knowledge and their interested related to the topic. Milatasari (2013), entitled Improving students' Ability in Writing through Inquiry Based Learning. The result of the study showed that IBL can make students more confident and active, developing their critical thinking, and understanding the concept. It means that in the first stage, students are free to develop questions so they can follow IBL strategy in the first stage properly. 
The second stage is investigating stage. This stage is gathering of information step. According to Escalante (2013), students get together in subgroups and narrow down the topic. They begin to gather information, inquire from difference sources, study and interview people, observe and even reformulate the question when necessary.

The objective of this stage is to explore students' knowledge about the topic. According to Abdelraheem and Asan (2006), Inquiry-Based Learning is the strategy to explore students' knowledge. It means that, in this stage, students in the classroom activities work in group to find new information related to the questions which were made by themselves as a result in the first stage.

The third stage is creating stage. According to Escalante (2013), in creating stage, "students begin to make connections. They synthesize what they have learned and shape new thoughts, ideas, and theories outside their prior knowledge and experience. This is the stage where students practice their composition skill." Hebrank (2000), the third cycle is the students try to observe the information related to the topic. In practical this stage, the students should make a list about the questions related to the topic that they are interested after collecting the data or information in investigating stage before.

The fourth stage is discussing stage. On the fourth stage, students share their new discoveries with other member of their sub-group. Escalante (2013), states that the discussing stage is to find out other classmates' findings involve themselves into a community-building process. By applying discussing stage, students are enthusiastic in doing this stage. It makes students feel free to speak to their friends without feeling shy or worry about it. They seldom get this chance in the process of learning experiences in their class. They can talk to each other by feeling free to explore their speaking.

In discussing stage, there is an interaction among students in classroom activities. The interaction is giving the effect on students speaking ability. The interaction among students give effects to each other for example: If some students have increased their motivation so it will give effects to others. According to Tarone (2005) states that the learners performance is always colored by that person he or she is talking with. It means that the interaction in discussing stage can give significant influences on students speaking ability. It means that this stage is the most important stage which gives impact to the significance of IBL strategy for speaking ability development case.

The fifth stage is concluding stage. On the last stage, students should look back at the question or the problem proposed. They analyze once more the whole research process and making conclusion. Hebrank (2000), states that concluding stage is the process which the student has to make conclusion about the topic being investigating and to explain the conclusion to others.

\section{The Factor outside of IBL Strategy}

The factors which can determine the result of this study are not only from the cycles or stages in IBL strategy but also some factors are from outside of IBL strategy such as: variety conditions, teachers, and students.

The condition is one of important factors for making the success of English teaching process particularly on teaching of speaking. Students perform a speaking task under a variety of conditions. According to Nation \& Newton (2009) states that performance conditions can affect speaking performance. It 
includes time pressure, planning, the standard of performance and the amount of support. It means the good condition can give the effective result in performance of speaking students in classroom activities.

The further factor is the teacher. The teacher leads whether the teaching process in the class is effective or not. There are some aspects that have to be considered by the teacher in order to make the process of teaching to be successful. According to Adam and Pierce (2006), There are four characteristics of effective teaching that the teachers have to be considered. The first is knowledge of basic principles and procedures. The effective or a good ELT must be based on sufficient basic principles and procedures in order to make the process of teaching is running properly. The second is planning and preparation. The effective teaching is representative from the good planning and preparation. It includes the planning of integration of learning to the curriculum, the students, teaching methods and strategies. The third is teaching Experience (practice). The fourth is flexible. The process of teaching can be changed to another setting. It means that effective teaching can be flexible based on contextual cues. It includes the different of students, classroom setting, environment and another context that can be affecting the process of teaching.

The teachers are important in the process of teaching and learning. The teachers lead the process of teaching itself. Nunan (2003), the teachers should circulate around classroom to ensure that students are on the right track and see whether they need help or not while they work in groups or pairs. According to Adam and Pierce (2006), The teachers are role model and the leader which leads the process of ELT to be a good process or poor process. It means that the teacher determine whether the process of teaching and learning of speaking successfull or not.

Nunan (2003) states that the teachers should provide an opportunity for students to talk by using group work and pair work and limit the teachers talk. It is important for the teachers to pay attention on giving many opportunities to the students to talk much than them. Based on the result of the posttest, the result showed there is an increasing score of students after three meeting treatments conducted. It means that the teacher in this case was successful in giving the opportinities students in talk more.

In this case, in applying IBL strategy, the teacher is a facilitator, a guidance, and a helper for the students. The role of teachers in IBL strategy is important. According to Fielding (2012), in IBL (Inquiry-based learning), the teachers play an active role throughout the process by establishing a culture where ideas are respectfully challenged, tested, redefined and viewed as improvable, moving children from position of wondering to a position of enacted understanding and further questioning. It means that the teacher is one of the factors which can give the significant impact on students speaking ability.

The further factor of significance of IBL strategy is student itself. The students are the centers of teaching process in IBL strategy. Inquiry-based learning is an approach to teaching and learning that places students' questions, ideas, and observations at the center of the learning experience (CBS:2013). It indicates that the students determine and choose their questions, ideas and the topic that they are interested. It means that students can determine their success in the process of teaching by themselves.

According to Brown (2000), students who can use the strategy are better language learners. Students can be more active in the class. They can be motivated 
to pay attention in class and to be interested in following the process of teaching and learning because they feel handle or control their language level. It shows that students who can follow the rule of IBL strategy in this case, they can get more active in the class and get higher score based on the result of the study as well as the result of posttest after several treatments conducted. It means that students are the centers in the process of IBL strategy where they determine the result of learning process itself. The process of teaching and learning can be successful or failed based on the student itself.

\section{CONCLUSION AND SUGGESTION}

\section{Conclusion}

Based on the result of this study, it can be concluded that there are two conclusions in this study where it answers the two research questions. The conclusions of this study are:

1. IBL strategy affected students speaking ability with average increasing score of 11,05 covering the four aspects (vocabulary, grammar, fluency and pronunciation) of speaking.

2. IBL strategy affected sufficiently significant $(0,05)$ on students speaking ability based on the result of pretest before IBL strategy was conducted and the result of posttest after IBL strategy was conducted.

\section{Suggestion}

\section{Suggestions to the Teachers}

1. English teachers, especially English teachers at senior high schools of south Bengkulu particularly on SMAN 7 Bengkulu Selatan have to try to apply IBL strategy as additional strategy in order to improve students speaking ability. The teachers could pay attention more how important IBL strategy in schools to be implemented particularly on teaching of speaking. They have to give many chances to students to explore their abilities in speaking English.

2. The teachers need to establish learning environment in order to make the process of applying IBL strategy to be successful.

3. The teachers have to learn more about IBL strategy in order to be applied as additional strategy in teaching of speaking and as one of various strategies which attract students in learning of speaking.

\section{Suggestions for Further Studies}

1. This study is recommended to conduct the study in other subject for example: IBL strategy on speaking ability of college students.

2. This study indicated that has a chance to the further research in conducting a case study about IBL strategy which is used by the teachers in developing listening ability at secondary schools.

\section{REFERENCES}

Abdelraheem, A., \& Aan, A. (2006). The effectiveness of inquiry-based technology enhanced collaborative learning environment. Intenational journal of technology in teaching and learning, 2(2), 65-87.

Adam, Cheryll., Pierce, Rebbecca. (2006). Differentiating instruction. Prufrock Press Inc. 
Andrews, Kenneth. (1980). The concept of corporate strategy, 2nd Edition. DowJones Irwin.

Arends, Richard I. (2004). Learning to teach: Sixth Edition.Glencoe/Mcgraw Hill Post Secondary: Amazon US.

Ary, Donald., Lucy, C.J, Chris, S. (2010). Introduction to research in education: eighth edition. Wadsworth Cangage Learning; USA.

Brown, H.D. (2000). Principles of language learning and teaching. New York: Longman.

Brown, H.D. (2000). Teaching by principles an interactive approach language pedagogy 2nd edition. new york: pearson longman.

Capacity Building Series. (2013) Inquiry-based learning. Ontario SchoolsSecretariat special edition. Retrieved from www.edu.gov.on.ca/eng/literacynumeracy/inspire/. On October 01 2017.

Cox, D. E., \& Connors, J. J. (2017). Learning styles and cognitive performance of secondary school pupils. Retrieved on 22, 15-23.

Creedy, D., Horsfall, J., Hand, B.(1992). Problem-based learning in nurse education: an Australian view. Journal of Advance Nursing, 17, 727733.

Creswell, J.W. (2013). Research design: qualitative, quantitative and mixed methods approaches. Sage publications.

Dewi, K.R.A., Padmadewi, N.N., \& Wedhanti, N.K. (2013). The implementation of inquiry-based learning in teaching english in Aura Sukma Insani Kindergarten. universitas Pendidikan Ganesha. Retrieved on October 112017 from http://ejournal.undiksha.ac.id/index.php/JPBI/article/view/5361.

Escalante, Patricia.2013. Inquiry-based learning in english as a foreign language class. Revista De Lenguas Modernas: Costa Rica.

Feletti, G. (1993). Inquiry based and problem based learning: how similar are these approaches to nursing and medical education?. Higher education research \& Development, 12(2), 143-156.

Fielding, W.J. (2012). Developing primary students' argumentation skills in inquiry-based mathematic classroom. Mathematic Education Research group Australasia: Australia.

Hebrank, Mary. (2000). “Why inquiry-based teaching and learning in the middle school science classroom?”. Retrieved from http://www.biology.duke.edu/cibl/inquiry/why_is_inquiry.htm>

Heijden, M.V.D . (2013). The perception of the use of inquiry based methods in the Chinese language classroom in IBO Primary Years program schools in the Asia Pacific region. United World College: Singapore.

Herrel, Adrienne L and Michael L. Jordan. (2012). Fifty strategies for teaching english language learners, 4th edition. Pearson: US

Horvart, I. (2016). Experimental research design. Springer International Publishing Switzerland: Switzerland.

Hughes, A. (2003). Testing for language teachers: second edition. Cambridge University Press: UK.

Intel Teach Website. (2013). Inquiry-based learning (linea). Retrieved on October 
(http://www.intel.com/content/www/us/en/education/k12/teachelements.html)

Johnson C., Scholes G., and Whittington M. (2006). Creativity in science and technology, values and creativity. Creativity Research Journal, 19, 105- 122.

Kenworthy, J. (1987). Teaching English pronunciation. Longman: London.

Key, James P. (1997). Research design in occupational education. Oklahoma State University: US.

Kindsvatter, R., Willia, W., \& Margaret, I. (1998). Dynamics of effective teaching. White Plains. NY: Longman.

Kuhlthau, Carol C., Leslie K. Maniotes., Ann K. Caspari. (2007). Guided inquiry (learning in the 21th century). Greenwood Publishing Group Copyright.

Leech, Geoffrey and Jan Svartvik. (2003). English grammar for today a new introduction second edition. Amazon: Routledge.

Lee, H.Y. (2014). Inquiry-based teaching in second and foreign language pedagogy. Journal of language Teaching and Research, vol. 5, No. 6 pp.1236-1244, November 2014 ACADEMY PUBLISHER: Finland.

Lestari, Endang. (2016). The implementation of inquiry-based learning in teaching english at

smp negeri 1 gemolong in 2015/2016

academic year. Universitas Muhammadiyah Surakarta. Retrieved from http://journals.ums.ac.id/index.php/JOLLIET/article/view/2126 on October 112017.

Luoma, S. (2004). “Assessing speaking”. Cambridge: Cambridge University Press.

Mendur, J., Mogea, T., \& Olli, S. Tresnawati. (2014). Increasing students' ability of writing descriptive texts based on inquiry-based learning at sma kristen tondano. English study rogram Universitas Negeri Manado.

Retrieved

from http://ejournal.unima.ac.id/index.php/komp/article/view/2816 on October 122017.

Milatasari, Y.U. (2013). Improving students' ability in writing through inquiry based learning. Universitas Sebelas Maret. Retrieved from http://jurnal.fkip.uns.ac.id/index.php/bhs_inggris/article/view/7878 on October $12 \quad 2017$.

National Capital Language Resources Center.(2015). Teaching world languages: a practical guide. The George Washington University: Washington DC.

Nation, I. S. P., \& Newton, J. (2009). Teaching ESL/EFL listening and speaking. esl \& applied linguistics Professional Series. Routledge Taylor \& Francis Group.

Nunan, D. (2003). "The impact of english as a global language on educational policies and practices in the asia-pacific region TESOL Oarterly", 37 (4), 589-613. 
Richards, J. C. (2008). "Teaching listening and speaking from theory to practice". Retrieved from http//iteslg.org/Articles/Kayi-Teaching, september 22 2017.

Ritchhart, Ron., Mark Church \& Karrin Morrison. (2011). Making thinking visible: how to promote engagement, understanding, and independence for all learners. Jossey-Bass: US.

Ross, R.J., and Morrison, A.R. (1995). American phisiological society. Retrieved from onlinelibrary.wiley.com on September 122017.

Sakdiah, H., Pali, M., Ardhana, I.W., \& Hitipeuw. (2015). The effectiveness of web- based learning inquiry method to increase students' independency of learning. Universitas Negeri Malang. Retrieved from http://journal.um.ac.id/id/index.php/j on October 12 2017.

Scardamalia, M. (2002). Collective cognitive responsibility for the advancement of knowledge. In CBS (special edition \#32). Retrieved from $\mathrm{http} / / \mathrm{cbs} / 2017$ on September 272017

Sherbiny, M. El. (2007). An expert system for multiobjective decision making. 'Retrieved from cu.edu.eg on August 122017.

Sholeh. (2008). Using inquiry-based learning strategy to improve descriptive writing ability of the second year students of MTs. Al Ikhwan Klitih Demak". Malang University: Malang.

Siegle, D. (2017). Experimental research on education. Neag School of Education. University of Connecticut.

Singh, Yogesh kumar.2006. Fundamental of research methodology and statistics. New Delhi: New age international publishers.

Sulastri, Sri. (2012). "Improving the students' reading skill by using inquirybased teaching and learning method" (Classroom Action Research at the Eight Grade of SMPN 2 Barat-Magetan in 2011/2012 Academic Year). English Education Department Graduate School, Sebelas Maret University.

Talis-Pisa Link. (2016). Teaching strategies for instructional quality. OECD retrieved from @ oecd.org. on oct 22017.

Tarone, E. (2005). Speaking in a second language. in E.Hinkel (Ed.), Handbook of research in second language teaching and learning (pp. 485502).Mahwah, NJ: Laurence Erlbaum Associates.

Thomson, C.B., \& Panacek, E.A. (2006). Research study designs: experimental and quasi-experimental. Air Medical Journal, 25(6), 242-246.

Thornbury, Scoot. (2005). How to teach speaking. Pearson: United Kingdom. Retrieved from http://www.amazon.co.uk on September 122017

Turkmen, H. (2009). An effect of technology -based inquiry approach on the learning "Earth, Sun \& Moon" subject. HKIEd APFLST. 10(1).

Wells, Alison. (2010). An investigation of inquiry-based learning in the inclusive classroom. Published thesis: University of Manitoba. 